\title{
Social Representations on Euthanasia between Students of Law and Medicine: A Comparative Analysis
}

\author{
Joicy Leide de França Santos, 1 \\ Orcid.org/0000-0002-8674-1373 \\ Edclécia Reino Carneiro de Morais ${ }^{1}$ \\ Orcid.org/0000-0001-8116-9104 \\ Renata Lira dos Santos Aléssio ${ }^{1}$ \\ Orcid.org/0000-0001-8548-2771
}

${ }^{1}$ Universidade Federal de Pernambuco, Recife, PE, Brasil

\begin{abstract}
The practice of euthanasia activates the debate about the scope of therapeutic efforts in limited situations and involves the society in the discussion of values and social beliefs implicated in the management of the person. The objective was to analyze the social representations about euthanasia between students of law and medicine. A free association questionnaire was applied with the inductor term: euthanasia, with 120 university students. The data were separately submitted to a prototypical analysis (IRaMuTeQ Software) and to a multiple correspondence analysis - MCA (R.TeMiS Software). Through the prototypical analysis, some variations were identified in the central core hypothesis, which referred to the possibility of two distinct social representations. Through the MCA, a lexical field was observed, linked to the image of death for the Medicine group and to values and norms for the Law group, with religion as a significant variable in the reorganization of the representational field, being able to accentuate a negative and condemnatory dimension on this practice.
\end{abstract}

Keywords: Euthanasia, bioethics, social representations.

\section{Representações Sociais sobre Eutanásia entre Estudantes de Direito e Medicina: Uma Análise Comparativa}

\section{Resumo}

A prática de eutanásia ativa o debate sobre os alcances dos esforços terapêuticos em situações limítrofes e implica a sociedade na discussão de valores e crenças sociais envolvidos na gestão da pessoa. Objetivou-se analisar as representações sociais sobre eutanásia entre estudantes de direito e medicina. Foi aplicado um questionário de associação livre com o termo indutor eutanásia para 120 universitários. Os dados foram submetidos separadamente a uma análise prototípica (Software IRAMUTEQ) e a uma

* Mailing address: Universidade Federal de Pernambuco, Centro de Filosofia e Ciências Humanas (CFCH), Av. da Arquitetura, s/n - $9^{\circ}$ Andar, Departamento de Psicologia, Cidade Universitária, Recife - PE, Brazil 50740550. Phone/Fax: (81) 2126 8270. E-mail: joicyleide@gmail.com

Support: Coordenação de Aperfeiçoamento de Pessoal de Nível Superior (CAPES). 
análise de correspondências múltiplas - ACM (Software R.Temis). Através da análise prototípica, foram identificadas algumas variações na hipótese do núcleo central, que remetem à possibilidade da existência de duas representações sociais distintas. Através da ACM foi observado um campo léxico ligado à imagem da morte para Medicina e a valores e normas para Direito, tendo ainda a religião como variável significativa na reorganização do campo representacional, podendo acentuar uma dimensão negativa e condenatória sobre tal prática.

Palavras-chave: Eutanásia, bioética, representações sociais.

\section{Representaciones Sociales sobre Eutanasia entre Estudiantes de Derecho y Medicina: Un Análisis Comparativo}

\section{Resumen}

La práctica de la eutanasia activa el debate sobre los alcances de los esfuerzos terapéuticos en situaciones limítrofes e implica la sociedad a la discusión de valores y creencias sociales involucrados en la gestión de la persona. Se objetivó analizar las representaciones sociales sobre eutanasia entre estudiantes de derecho y medicina. Se ha aplicado un cuestionario de asociación libre con el término inductor eutanasia en 120 universitarios. Los datos fueron sometidos separadamente a un análisis prototípico (Software IRAMUTEQ) y a un análisis de correspondencia multipla-ACM (Software R. Temis). Mediante el análisis prototípico, fueron identificadas algunas variaciones en la hipótesis del núcleo central, que remiten a la posibilidad de la existencia de dos relaciones sociales distintas. Mediante la ACM fue observado un campo léxico relacionado con la imagen de la muerte para Medicina y a valores y normas para Derecho, teniendo encuenta la religión como una variable significativa en la reorganización del campo representacional, pudiendo subrayar una dimensión negativa y condenatoria sobre tal práctica.

Palabras clave: Eutanasia, bioética, representaciones sociales.

Attempts to delimit the end of life give rise to controversial discussions that pervade scientific, political and religious knowledge and discourses. These discussions are signified by cultural, temporal and social intersections (Siqueira-Batista \& Schramm, 2004). Martin (1998) argued that, in view of the dissent that constitutes the discourses produced regarding the end of life, to view death as a phenomenon of an entirely biological order is sometimes a comfortable path. Particularly in Western culture, the handling of this theme leads to anguish faced with the idea of finitude. However, this type of simplification ignores the reflection on the complexity and plurality of meanings about life and death, incorporating the idea of being human solely as an organism rather than from a biopsychosocial subject view (Carmona, Santos, \& Fonseca, 2011).

By the 1960s, the intensification of technological progress favored the creation of biomedical resources that translated into devices and medications capable of prolonging and maintaining life. The use of these new strategies - coupled with the excessive freedom of power exercised by physicians, with regard to interventions on the body and the life of the patient, raised questions about the forms of care, especially with regard to the decision regarding death and the management of diseases (Menezes \& Ventura, 2013). According to Diniz and Guilhem (2017, p. 15) "technological development has given rise to unexpected moral dilemmas related to the biomedical practice". Thus, it became significant to discuss methods related to "how to die", taking into account the subject's autonomy, suffering and dignity the themes that make up the core of bioethical discussions (Felix et al., 2013).

In a brief historical overview, Diniz and Guilhem (2017) indicated changes in the social and moral perspective that contributed to the 
emergence of bioethics, such as: research in the Nazi concentration camps, the two world wars and human rights treaties. In 1974, the National Commission for the Protection of Human Subjects of Biomedical and Behavioral Research emerged in the United States. The result of their work culminated in the publication of the Belmont report, which served as a driving force for the consolidation of bioethics in university centers, advocating biological knowledge and ethics as essential for respect for human values. Based on this foundation three universal ethical principles were constructed: respect for people, beneficence and justice.

The Belmont report began to be used in biomedicine as a reference in decision-making regarding controversial medical issues (Diniz \& Guilhem, 2017; Ribeiro, 2006). Bioethics presents itself as an interdisciplinary scientific field, mediating the knowledge produced in each context and culture, considering the diversity of beliefs and values that intersect themes such as euthanasia (Kovács, 2003). In this field, euthanasia gains prominence because it forms part of a controversial background, which invokes different values and social beliefs in the taking of positions regarding the end of life.

Throughout history the idea of euthanasia has been referred to using different names. Currently, although there is still a fragile consensus regarding its outline, euthanasia is understood as a practice that shortens the end of life in terminal situations, in order to provide subjects with the possibility of avoiding suffering and exercising their autonomy and dignity. Accordingly, the existence of a multitude of ways of classifying this practice is recognized. Euthanasia can be typified as: active, passive, voluntary and involuntary. The active form involves the action of another, who acts in favor of the provocation of euthanasia, while the passive form refers to the omission of resources, such as: devices or medications, in order to cause the death. The voluntary and involuntary involve the context in which the patient has conditions to consent to the procedure or not, respectively (Felix et al., 2013; Menezes \& Ventura, 2013). Another practice related to the debates about autonomy and dignity in situations of terminality of life is dysthanasia. According to Felix et al. (2013), dysthanasia can be understood as "bad death" since it is a procedure in which the aim is to prolong the life in biological terms for as long as possible through the use of drugs or devices. Dysthanasia does not consider the suffering of the subject or the quality of the terminal process.

Orthothanasia is related to the sense of a "good death" and "dignified death", since its concept proposes death in its time, without being anticipated or delayed, allowing the patient all the necessary care to avoid pain and suffering (Godinho, 2017).

In Brazil, euthanasia is a criminal procedure that raises various positionings and has caused social and political clashes. The arguments in favor, are based on the principle that the subjects should have the right to the decision regarding their own lives, with euthanasia also being interpreted in a humanistic way, since it frees the subject from suffering and precarious conditions of quality of life in terminal situations, in which there is no prospect of improvement.

Nonetheless, there are those who insist that once decriminalized, euthanasia may be misapplied. In this scenario, the patient could be affected by psychological pressures exerted by third parties driven by financial interests or others unrelated to altruistic ends. Among the opposing arguments, from the religious perspective, it is recommended that life should be treated as sacred and inviolable (Carmona et al., 2011). Kovács (2003) and Martin (1998) argued that in Brazil there is a legal paradox since the right to life and the right to human dignity are guaranteed by law, foreseen in the citizen's bill of rights of the 1988 Constitution, however, the right to die is not recognized. Therefore, patients do not occupy the central place in the management of decisions regarding how to deal with their death processes, nor are they autonomous in relation to the decision about methods of life termination. The insecurity about the lack of legislation directed toward this issue drives the professionals' conduct in the maintenance of dysthanasia as a preponderant practice in the country. Orthothanasia, although decriminalized 
since 2010, is still subject to disagreements and its practice is guided by law (Felix et al., 2013).

The controversial atmosphere that encompasses diverse positionings regarding the autonomy of the subject provokes the emergence of bioethical debates about the practices of care, engaging diverse knowledge and thus forming a fertile ground for reflections in terms of social representations (SRs). The social representations theory (SRT) allows us to reflect on the appropriation of scientific knowledge by common sense. According to Moscovici (1976) SRs involve a set of behaviors, cognitions, beliefs and norms that circulate and crystallize through practices and discourses. However, these common-sense theories have a dynamic rather than a static character, which keeps them susceptible to change.

According to the author, representing is not an act of passivity, that is, the product of the representation is not the creation of a replica of the object. In fact, it deals with the absence of the object itself and the need to evoke it. Each time something or someone is represented, that phenomenal reality about the world is modified and recreated. The subject is understood as the constructor of the reality, since the subject is considered active in this process and since the representations do not deal with the pure reproduction of the object. Involved in the process of appropriation and interpretation of the phenomena in the world, the subject is also modified and constructed by this social reality. Therefore, social representation can be considered to be a product and process of elaboration of reality. In terms of dimension and by virtue of its dynamic character, there is no way to specify where a social representation begins or ends. It is important to note that not all representations are social representations. There are also individual representations. However, every representation is a representation of something, whether directed toward an individual, in the case of the individual representation, or toward a group, as in social representations (Moscovici, 1976).

According to Santos (2005), the object of the representation must have social relevance to the group and can take different forms according to the context. On one hand, the object is polysemic in terms of making meanings and its naming. On the other hand, it can be polemic, as it sometimes involves conflicts of values and controversies. It can also be said that identity elements that circumscribe the groups characterize the object of representation. The social practices act in the construction of social representations while the social representations also guide the group practices. According to Moscovici (1976, p. 46), "the social representation is the preparation for action, not only because it guides behavior, but above all because it reshapes and reconstitutes the elements of the environment in which the behavior must take place".

This article focuses on the structural approach, since it is dedicated to the investigation of the organization of the elements that constitute a social representation. Part of this approach is to analyze the importance and function of the central elements, the hierarchies and maintenance elements of the functioning and dynamics of the SR (Santos, 2005). Social representations are organized into two systems: the central core and the peripheral zones. The central core brings together the elements that fundamentally characterize the SR. This exerts a structuring role and its absence could mean the inexistence of an SR object. It then functions as an "organizing principle" (Sá, 2002). As a structure, the central core mainly performs the generating and organizing functions of the SR. The first function is linked to the creation, transformation and signification of the elements that form the SR, while the second concerns the definition, "unification" and "stabilization" of the SR. The central core "determines the nature of the bonds that unite in themselves the constituent elements of the representation" (Abric, 1994, p. 22).

The peripheral zones act to protect the central core, as well as help in the mode of economic functioning of a social representation. In other words, the peripheral zones act in a way that avoids the need for consistency in analyzing situations in relation to the central core (Flament, 2001). They perform a normative function, in order to analyze situations according to the 
organizing principle. They act as a "buffer" between foreign schemas that seek to refute the central core, preventing it from easily changing: "the disagreements in reality are absorbed by the peripheral zones, which thus ensure the relative stability of the representation" (Flament, 2001, p. 178). In the structural approach, it is understood that it is necessary to share the same central core so that elements can be considered to be constituents of the same social representation (Flament, 2001).

In this context, the aim was to comparatively investigate the structure of the social representations regarding euthanasia for medical and law students, in order to comprehend the similarities and differences that make up these social representations. It is relevant to investigate the social representations of euthanasia in relation to students in the areas of law and health, since they may occupy a space of power and encounter it in their practice with discussions and situations involving this object.

\section{Method}

This was a quantitative-qualitative exploratory study.

\section{Participants}

A total of 120 students from public universities in Pernambuco, over 18 years of age, enrolled in medical $(N=60)$ and law $(N=60)$ courses participated in the study. Students from all years of the courses were selected during the two academic semesters of 2016 in the months of April to June and from August to September. Taking into account the full number of participants, $55 \%$ of the sample was composed of women and 45\% men. Regarding the religion variable, $67.5 \%$ declared themselves non-practicing (of these, $30.8 \%$ were medical students and $36.7 \%$ law students) and $32.5 \%$ were practitioners (of these, $13.3 \%$ were medical students and $19.2 \%$ were law students).

The family income was reported through an open question, with great variability (from 1 minimum wage up to 23 minimum wages). The income reports were organized according to each course. Among the medical students, 13 participants did not report their family income, 25 reported an income of up to 8 minimum wages (MWs), 19 between 08 and 23 MWs and 03 participants reported income above $23 \mathrm{MWs}$. Among the law students, 14 participants did not report their family income, 31 reported an income of up to $8 \mathrm{MWs}, 12$ between 8 and 23 MWs and 03 participants reported income above 23 MWs. Regarding the political orientation, among the medical students 20 declared a central position; 16 left and center-left; 06 right; 03 other positions (anarchist and liberal) and 15 reported having no political orientation. Among the law students, 32 declared a left position; 14 central; 03 right; 03 other positions and 09 did not report a political position.

\section{Instruments}

Data collection was performed through the self-application of an association or free word evocation questionnaire, with euthanasia as the inductor term. For this, the participants were asked to write the first 5 words that came to mind when thinking about the term euthanasia. Subsequently, they were asked to place the words chosen in order of importance as a response to the inducing stimulus. A socioeconomic identification questionnaire was also applied.

\section{Data Collection Procedures}

The study was carried out in different spaces of the university (corridors, room, libraries). The questionnaire responses were later digitalized in Microsoft Office Excel spreadsheets, generating the initial corpus of the study.

\section{Data Analysis Procedures}

The data were analyzed using the IRaMuTeQ and R.TeMiS programs. IRaMuTeQ is free software for analyzing textual data. The type of analysis performed using IRaMuTeQ was prototypical, a technique designed by researchers of the structural approach of the theory of social representations (Camargo \& Justo, 2013). The expressions evoked and hierarchized by the participants were distributed, 
by prototypical analysis, into four quadrants. The first grouping included the expressions that were more frequent and hierarchized as more important, thus identifying a hypothesis for the probable central core.

The words that formed the second quadrant or first periphery referred to elements that had a high frequency of evocations, however, which were not evaluated as having a high degree of importance. The third quadrant or zone of contrast includes the elements that had greater degree of importance and lower frequency. The fourth quadrant or the last periphery includes the words with a lower degree of importance and lower frequency of evocations. The elements of these 3 quadrants together form the peripheral zone.

Also using IRaMuTeQ, the calculations of frequencies and multiple frequencies were extracted for the performance of the centrality test of the evocations. In this study, the criterion for the centrality test of the representational elements was the calculation of "frequency drop" (Andrade, 2014; Morais, 2018). From the comparison between the frequency of each of the words initially distributed in the first and second quadrant of the prototypical analysis with the general index calculated through the following formula, the final arrangement of the elements present in the first quadrant of the prototypical analysis was determined:

The frequency drop calculation described above acts as a parameter to regulate the distribution of words in the first quadrant, guaranteeing only the maintenance of terms with a strong index $(\mathrm{FD} \leq 40 \%)$ of evocation among the three most important terms.

The R.TeMiS menu was developed by Gilles Bastin and Milan Bouchet-Valat (2014). It is also a graphical environment for the use of the $\mathrm{R}$ statistical program in the analysis of textual data. This menu offers the possibility of lemmatization of the text, transforming the words or expressions into terms through the radicals of the words. The R.TeMiS program was used for the multiple correspondence analysis (MCA). Unlike IRaMuTeQ, R.TeMiS allows the analysis of correspondence with the evocations (lower volume of text), accepts variables with only two modalities for the Correspondence Analysis (CA) calculation and performs the MCA, either from the co-occurrence calculation or without this calculation.

Multiple correspondence analysis, with free associations, offers the possibility to reorganize the data evoked from the association of the variables with the respective factors (or latent variables). The evoked contents were then distributed in a factorial plane according to their greater approximation (association) with the factors, thus forming lexical fields associated with the poles of each factor (Oliveira \& Amaral, 2007).

\section{Ethical Procedures}

This study was approved by the Research Ethics Committee of Federal University of Pernambuco (UFPE), under authorization No. CAEE: 53822416.7.0000.5208. As recommended in the ethical criteria followed, the participants were invited to participate in the study and gave their agreement through the signing of the consent form.

\section{Results and Discussion}

First, the hypothesis of structure of the representation for each course is presented and then, through a comparative approach, the modulations of the representational field are investigated.

\section{Social Representations of Euthanasia among the Medical Students}

A total of 297 expressions were obtained for the euthanasia inductor term among the medical students, with 84 being different. The general frequency drop percentage was $39.4 \%$. As a result of this index, all the expressions present in the first or second quadrants (percentage lower than $39.4 \%$ ) became the hypothesis of the central core while expressions that presented a percentage higher than $39.4 \%$, started to occupy the peripheral system (Figure 1). 


\begin{tabular}{|c|c|c|c|c|c|c|c|c|}
\hline \multirow{21}{*}{$\begin{array}{l}<5.38 \\
\text { Frequency> } \\
=5.38\end{array}$} & Evocations & $\mathbf{F}$ & $\mathbf{I}$ & FD & Evocations & $\mathbf{F}$ & $\mathbf{I}$ & FD \\
\hline & Autonomy & 6 & 2.3 & $16 \%$ & School & 16 & 2.9 & $43 \%$ \\
\hline & Relief & 14 & 2.3 & $21 \%$ & Pain & 7 & 3.1 & $57 \%$ \\
\hline & Freedom & 8 & 2.1 & $25 \%$ & End & 6 & 3.3 & $50 \%$ \\
\hline & Family & 8 & 3.1 & $25 \%$ & & & & \\
\hline & Suffering & 41 & 2.9 & $36 \%$ & & & & \\
\hline & Death & 41 & 2.9 & $36 \%$ & & & & \\
\hline & Dignity & 5 & 2.2 & & Rest & 5 & 3.2 & \\
\hline & Right & 5 & 2.8 & & Give up & 4 & 3.5 & \\
\hline & Disease & 4 & 2.8 & & Controversy & 4 & 4 & \\
\hline & Decision & 3 & 2.7 & & Life & 3 & 4.7 & \\
\hline & Assisted suicide & 3.2 & 2 & & $\begin{array}{l}\text { Terminal } \\
\text { patient }\end{array}$ & 3 & 3 & \\
\hline & Relieve suffering & 3 & 1.7 & & Backspace & 2 & 4.5 & \\
\hline & Will & 3 & 2 & & Murder & 2 & 4 & \\
\hline & Option & 2 & 1 & & Terminal & 2 & 3 & \\
\hline & Respect ' & 2 & 2.5 & & Law & 2 & 3 & \\
\hline & Difficult decision & 2 & 1 & & Understanding & 2 & 3 & \\
\hline & Doubt & 2 & 2 & & $\begin{array}{l}\text { Switch off } \\
\text { devices }\end{array}$ & 2 & 4 & \\
\hline & Peace & 2 & 1 & & Devices & 2 & 5 & \\
\hline & Compassion & 2 & 2.5 & & $\begin{array}{l}\text { Terminal } \\
\text { illness }\end{array}$ & 2 & 4.6 & \\
\hline & & & & & Wish & 2 & 4 & \\
\hline
\end{tabular}

Figure 1. Frequency (F), Order of Importance (I) and Frequency Drop (FD) of free associations on euthanasia for the medical students.

The elements of the first quadrant: autonomy, relief, freedom, family, suffering and death, constituted the hypothesis of the central core, being linked to the context of organization and definition of the social representation of euthanasia for the medical students. These are elements that had a high frequency and were importance for the group. The evocations of autonomy and freedom are closely linked to the notion of "dignified death" and the subject as an active part in the decision-making process on how and when to die (Felix et al., 2013; Martin, 1998). They also reflect the bioethical discussions about manipulation and power over the other's body (Diniz \& Guilhem, 2017). This body that has life, has its own conceptualization and limits marked by a series of controversies (Martin, 1998). The expressions relief and suffering refer to a dimension of conceptualization and belief in euthanasia as a practice that frees the subject that is affected by a terminal phase, that is, they refer to a practice for humanistic purposes (Carmona et al., 2011). The strong presence of the word death seems to be linked to the objectivation of euthanasia for medical students and to the dimension of solidity of the representation.

Although the representations have a dynamic character, the central core has a certain degree of stability and constancy. What prevents the social representation from constantly changing 
(Flament, 2001), as previously stated, is that the peripheral system has a function of protection of the central core, with it having fundamental relevance in maintaining the stability of an SR. It acts as an obstacle so that the foreign schemas do not easily reach the central core, which is the component that defines the social representations (Flament, 2001; Sá, 2002; Santos $\&$ Almeida, 2005). Some of the expressions that make up the second and third quadrant namely: option, dignity, relief from suffering, choice, compassion, respect, illness and right; also seem to refer to the notion of belief in euthanasia as a practice that frees the subject from a final state of suffering, reinforcing the elements of relief and suffering present in the hypothesis of the central core. They are representational contents that are probably anchored in the idea of an act of compassion and respect for autonomy and dignity in what concerns the life and body of the other (Carmona et al., 2011). These elements could be linked to the normative dimension of representations because they refer to the idea of social rules. For the group of medical students, they are rules regarding rights and respect for the other (Santos \& Almeida, 2005).

The evocations doubt, difficult decision, assisted suicide and relief from suffering allude to a controversial dimension of the euthanasia object for the medical group and demonstrate the belief in the installation of a cognitive conflict or of difficulty in the decision making in this practice. This dimension can also be observed in the presence of conflicts related to the beliefs about the object, so that the representational contents mentioned above reveal how the peripheral system can support the heterogeneity of the group investigated, as for some euthanasia refers to relief, while for others it can configure a difficult decision.

\section{Social Representations of Euthanasia among the Law Students}

A total of 298 expressions were obtained for the euthanasia inductor term among the law students, with 133 being different. The general frequency drop percentage was $39.5 \%$. In Figure 2 it is possible to observe the evocations produced by the students of the law course.
The words that were located in the first quadrant, following the performance of the centrality test, comprised the central core of the euthanasia representation for the law students, namely, relief, dignity, right, family, freedom and suffering. The family appears as a figure of importance in the literature on euthanasia because it has a role of legal responsibility in relation to the family member, sometimes in a state of serious health impairment and with limited conditions to answer for him/herself (Felix et al., 2013).

The expressions dignity, right and freedom seem to refer to the axiological dimension of the representations, as shared values regarding the right of the other in the decision of when and how to die. The first quadrant appears prominently in the evocations: freedom and right, the anchorage of which can refer to fundamental rights, as something that enables the subject to be autonomous in relation to the decisions about his/her body and the limits of his/her life.

In the second quadrant or first periphery, the words death, life, and choice appear with a similar frequency drop and a high level of frequency. These expressions refer to controversial and conflicting dimension related to the meanings that are made about the idea of life, death and its limits. They also relate to the autonomy of choice in relation to who holds or should hold power over one's own body and the body of the other. Is it the subject him/herself? The family? The health or legal professionals? The law?

The religion element, also belonging to the first periphery, appeared as a component that plays an important role in the definition of group attitudes, beliefs and practices regarding the euthanasia object. Religion has such a prominent place in the positioning and construction of social representations regarding euthanasia, that this study used religious practice as a variable modality for the comprehension of the possible variations between social representations. The free evocation of the word religion thus lends support to the choice of this work to control for the religious practice of the participants. The correspondence analysis that we will present illustrates the importance of the religious practice in the configuration of differences in the representational field of euthanasia. 


\begin{tabular}{|c|c|c|c|c|c|c|c|c|}
\hline \multirow{3}{*}{$\begin{array}{l}<5.46 \\
\text { Freque } \\
\text { ncy> = } \\
5.46\end{array}$} & Evocations & $\mathbf{F}$ & I & FD & Evocations & $\mathbf{F}$ & I & FD \\
\hline & Relief & 8 & 2.4 & $25 \%$ & Disease & 9 & 3.8 & $55 \%$ \\
\hline & Dignity & 10 & 2.4 & $20 \%$ & School & 10 & 2.6 & $40 \%$ \\
\hline & Right & 8 & 1.1 & $0 \%$ & Death & 30 & 3 & $43 \%$ \\
\hline & Family & 9 & 3.3 & $33 \%$ & Religion & 6 & 3.7 & $66 \%$ \\
\hline & Freedom & 9 & 2.1 & $0 \%$ & Life & 10 & 2.6 & $40 \%$ \\
\hline & Suffering & 19 & 3 & $31 \%$ & & & & \\
\hline & Evocations & $\mathbf{F}$ & $\mathbf{I}$ & FD & Evocations & $\mathbf{F}$ & I & FD \\
\hline & Autonomy & 5 & 2.8 & & Decision & 4 & 3.2 & \\
\hline & Taboo & 4 & 2.8 & & Respect & 3 & 4.3 & \\
\hline & Right to life & 4 & 1.5 & & Medicine & 3 & 4.3 & \\
\hline & Pain & 4 & 2.8 & & Hospital & 3 & 4.3 & \\
\hline & End of suffering & 3 & 1.7 & & Rest & 3 & 3 & \\
\hline & Subjectivity & 3 & 2.7 & & Terminal illness & 3 & 3 & \\
\hline & Conflict & 2 & 2 & & Controversy & 3 & 4.3 & \\
\hline & Sadness & 2 & 2.5 & & Need & 3 & 4 & \\
\hline & Despair & 2 & 2.5 & & Release & 3 & 3.3 & \\
\hline & Responsibility & 2 & 1.5 & & Comfort & 3 & 3.3 & \\
\hline & Relieve suffering & 2 & 1.5 & & Love & 2 & 4 & \\
\hline & & & & & Planning & 2 & 3 & \\
\hline & & & & & Pity & 2 & 3.5 & \\
\hline & & & & & $\operatorname{Sin}$ & 2 & 4.5 & \\
\hline
\end{tabular}

Figure 2. Frequency (F), Order of Importance (I) and Frequency Drop (FD) of free associations on euthanasia for the law students.

The term "disease" also stands out in the periphery by referring to one of the elements that regulates the practices, values, attitudes and beliefs about euthanasia. In addition to the beneficent intention of the practice, the notion of a body afflicted by a serious illness with irreparable suffering is a necessary condition for distinguishing the practice of euthanasia from suicide or homicide.

In the contrast zone, consonant expressions emerged with the central core hypothesis, namely autonomy, right to life and end of the suffering. The contrast zone illustrates the sphere of bioethical conflicts with regards to the right and autonomy, the dignity of life and manipulation of one's own body and the body of the other, as suggested by the words pain, sadness, and despair, which refer to beliefs in the emotions that may be linked to the euthanasia object.

The term taboo appeared prominently in the third quadrant. One can reflect on this element linked to the evocation death. Death and finitude are seen as difficult to deal with, especially in the West, and are sometimes healed through silence on the subject (Martin, 1998). 
Comparison between the Social Representations of Euthanasia of the Medical and Law Students

Although there were elements shared by both groups in the composition of the central core hypothesis and periphery of the SR, there were also unique elements related to the functioning of each group. According to the reading of the structural approach regarding social representations, it is necessary for there to be the same central core to be able to consider that groups share the same social representation. The change of elements in the organizing and defining principle of social representations can bring about a different meaning for the SR, configuring it as a new social representation (Flament, 2001; Sá, 2002). Thus, one can think of the hypothesis that the medicine and law groups, although they shared elements, represented the euthanasia object differently.

It was observed that both groups shared the elements relief, family, freedom and suffering in the first quadrant. Suffering and relief may be tied to the groups' dimension of emotions in relation to euthanasia. The family evocation is a prominent element and can refer both to the relationship of medical and law professionals with the family of the subject who wishes or not to practice euthanasia, as well as the subject's relationship with the family in this circumstance. The words dignity and right appear with greater force for the law group because they compose the hypothesis of the central core of the SR, provoking an identity dimension while they appear in the contrast zone for the medical group.

The evocations of autonomy and death stand out as part of the central core hypothesis for the medical group. Autonomy may be linked to the normative dimension of the SR, as something that could be assured to the subject who wishes to practice euthanasia. This term also refers to the bioethical conflicts in relation to those who have power over the body and the decision regarding the methods of how to die, referring to the dilemmas of the physician's profession: how to respect the autonomy of the patient?

For the prototypic analysis, the sample was divided by course, aiming to evidence a central core hypothesis of the euthanasia SR for each group studied. The multiple correspondence analysis helped to interpret the association of representational contents with previously controlled variables, in this case, the course, gender and practice of religion. No differences were observed regarding gender, however, the representational field of euthanasia presented modulations according to the course and the practice of religion (Figure 3).

Factor 1 (horizontal axis) shows the polarization between the course variable and the elements with the highest contribution index for this factor, with the percentage of inertia being $54.3 \%$. The medicine course variable is located at the positive pole and the law course variable at the negative pole. Distribution was identified between contents linked to a reflexive analysis on euthanasia versus contents related to practical considerations about the object. This variation in positions between students of law and medicine could indicate attitudes related to the types of decision-making requirements in their professional practices.

The elements with the highest contribution percentage for each course are located near the lateral ends of the figure. The positive pole of the horizontal axis was named: practical, by virtue of the practical connotation that circumscribed the contents most associated with this pole, namely: pain, death, terminal, law, terminal patient. It is generally understood that the terms most associated with the medical course variable are concerns related to the praxis of the physician. More specifically, how to handle the practice of euthanasia considering that the patient is an individual, a body, feels pain, falls ill, suffers, lives and dies. What criteria would guide the practice of euthanasia? Who would the subjects be that would ask for it? What is the place of medicine and the physician faced with this demand?

In the literature, the elements death, terminal and terminal patient refer to the reflection on the very conceptualization of the term euthanasia. The terminality situation is one of the criteria used by Menezes and Ventura (2013) to discuss the conceptualization of euthanasia. The abbre- 


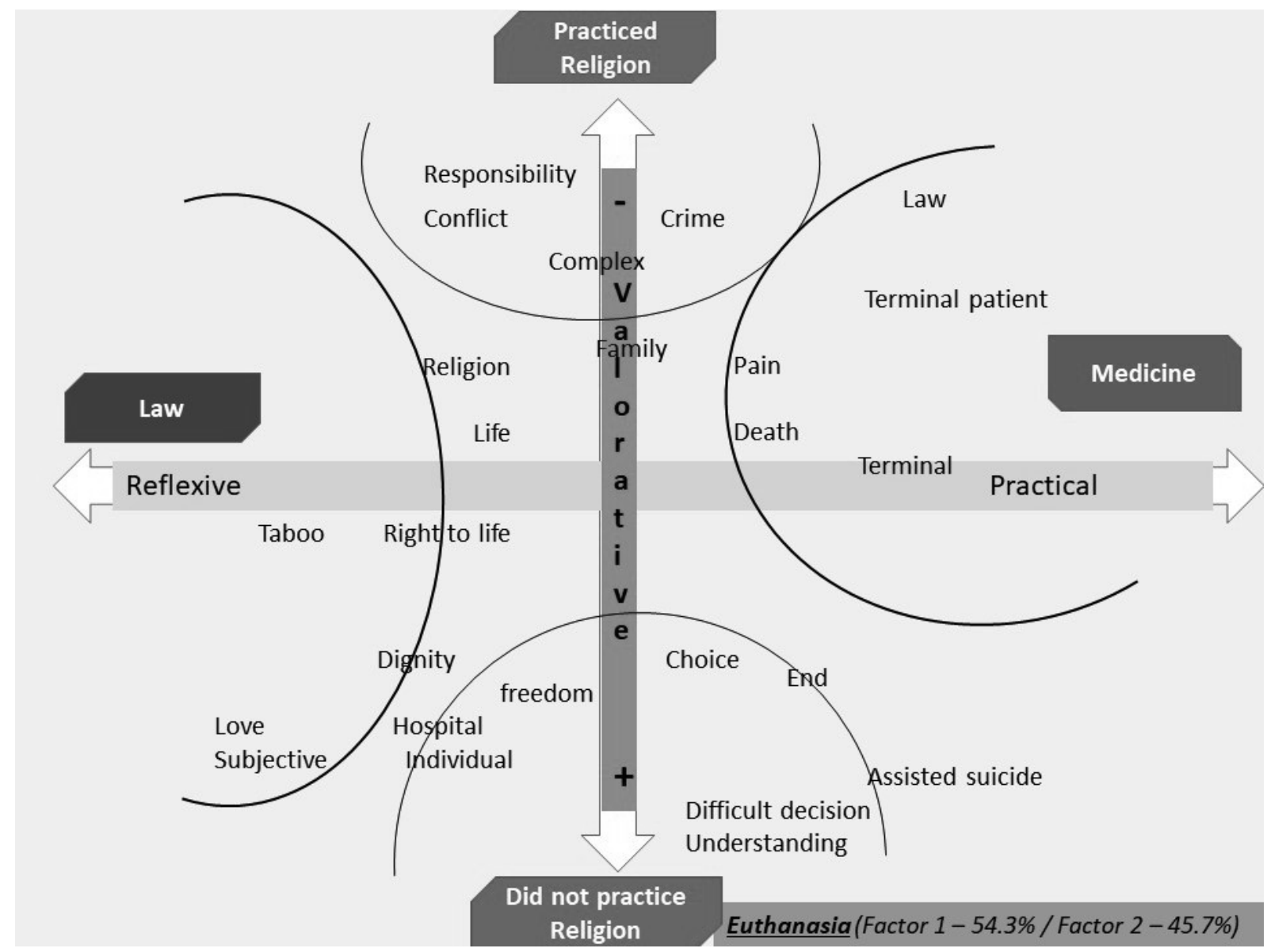

Figure 3. Factorial projection of free associations from the analysis of multiple correspondences or the two groups studied (students of law and medicine).

viation of life and consequently the contact with death is part of the theoretical-practical reflections on this theme. It is known that there is no consensus when talking about life or death in the various fields of scientific, religious, political or social knowledge (Siqueira-Batista \& Schramm, 2004). Pain is a strong element that appeared in this practical dimension for the medical course students. The emergence of technologies capable of prolonging and maintaining life will elicit from the medical professional reflections on the forms of care and how to manage this pain (Ribeiro, 2006). This component is also linked to the dimension of the emotions that give rise to the practice of euthanasia, since the presence of pain is used to think of euthanasia as a way to escape this reality in situations of terminality (Menezes \& Ventura, 2013). Accordingly, Bioethics covers reflections on the dignity of the subjects and the autonomy they enjoy or not in relation to their bodies. These debates evoke the positioning of the professionals that deal with the management of the care practices for the individuals' bodies (Carmona et al., 2011).

The law course variable was located on the negative pole of the horizontal axis. This was called reflexive because of the most significant elements that composed it, namely: taboo, right to life, dignity, love and subjective. These terms may be related to the theoretical-conceptual possibilities of looking at this object from the scientific, social and political fields of reference that the law group made regarding euthanasia. This discussion also refers to the practice, since the content of these reflections turns to the applicability of euthanasia and the demands that may arise for law professionals in dealing with this object.

In the literature, the taboo element is strongly linked to the discussion on euthanasia as it is inherent to the reflection about death 
and finitude when this point is touched upon. Siqueira-Batista and Schramm (2004) insisted that, particularly in western culture, the theme of death or end of life remains veiled due to generating uncertainties and even suffering. In this context the perpetuation of silence emerges as a way out of the delicate and controversial issues being contemplated (Martin, 1998).

The expression "right to life" may be related to the dimension of practical and evaluative reflection of the social representation of euthanasia for law students since this professional deals with the viability and lawfulness of actions in society. This also goes back to the bioethical discussions on the empowerment of individuals regarding the decisions that affect their bodies and lives (Kovács, 2003; Ribeiro, 2006). The elements of dignity and love can refer to the evaluative dimension of the social representations of euthanasia for the law group. In the conceptualization regarding euthanasia it is considered that this practice can be interpreted with the aim of beneficence for the subject, mercy, that is, an act of love. In this system of thought this is explained due to the fact that this practice rids the subject of a condition of suffering and irreparable difficulty. Thus, according to the bioethical principles, it would also promote the dignity of the subjects by providing decisionmaking power over how to manage their health condition and the death process.

Religious adherence obtained a strong association for factor 2 (vertical) of the correspondence analysis, demonstrating a strong contribution to the polarization of contents in a valorative dimension regarding euthanasia. Specifically, an association between adherence to a religious practice and a negative and condemnatory attitude toward euthanasia was highlighted. The family and responsibility elements allude to the reflection on who should hold the power of decision regarding the practice of euthanasia. At the same time, the expressiveness that the term family gains in these social representations of euthanasia demonstrates a dimension related to the practice, so that the decision-making process in this respect seems to invoke family participation, either directly or indirectly. However, the elements of crime, complexity and conflict can refer to the religious arguments also used to justify the criminalization of euthanasia. These maintain that life is sacred and inviolable. Considering that life and death belong to God, then it would not be up to the subject or relatives to decide how and when a life should end. In this sense, to break with this order is to transgress a religious standard/law. The idea of conflict and complexity may be related to other religious standards, especially those of Christian origin. As, although life belongs to God in this perspective, man also has the right to freely arbitrate in his decisions (Carmona et al., 2011).

At the negative pole, the association of the not practicing religion variable was identified. The elements that composed it were: hospital, individual, choice, freedom, end, assisted suicide, difficult decision and understanding. The elements of this pole allude to a more reflective than condemnatory dimension, when compared to the positive pole. The elements, hospital, individual and assisted suicide, may be related to the way of practicing euthanasia and the ways of interpreting it. The end element, however, refers to the terminality, which is decisive for the conceptualization of euthanasia. Although there is no consensus on the concept of finitude, death appears as a component inherent to this discussion (Martin, 1998).

The elements, freedom, choice and understanding highlight a position favorable to the right of choice and freedom in the decisionmaking process. The term difficult decision, accentuates the controversial and socially sensitive character for the performance of this decision making.

\section{Final Considerations}

The analysis developed in this article made it possible to verify variations between the global organization of the central elements of the social representations of euthanasia for students of law and medicine, allowing the construction of the hypothesis about the existence of two distinct social representations regarding this object. The 
structural approach proposes that the place of coherence of a social representation is its central core, an argument that ratifies the hypothesis of different social representations for groups that have varied elements and organization in their central cores, since the global coherence of the representation would be altered due to changes in its defining and organizing principle. In this way, it was possible to identify, through the prototypical analysis, a variation between one side, a normative representation, supported in the practice and objectified in death for the medical students, and on the other, a representation based on a more collective and reflexive analysis about euthanasia, concerned with values and emotions linked to the concept of euthanasia, for the law students.

The multiple correspondence analysis (MCA) carried out helped to comprehend the specificities in the fields of meanings that each group constructed regarding euthanasia. It was possible to identify two polarizations in this analysis framework, one linked to the association with the course and the other to an adherence to religious practice. Concerning the course, the multiple correspondence analysis ratified the hypothesis proposed by the prototypical analysis, in which variation between the meanings that students make about euthanasia rest on an antinomy between reflection and practice. In this sense, the more specific contents for students of law and medicine, also evidence a variation in the anchorages between a field that is more reflective regarding euthanasia versus a focus on the practical context.

Regarding adherence to religious practice, a distinction between more and less favorable positions regarding the practice of euthanasia stood out in the MCA. On one hand, there was a condemnatory and resistant tone to autonomy and freedom of choice in the context of euthanasia, associated with the practicing religion variable. On the other hand, associated with not practicing religion, there were elements related to the defense of values regarding free choice and individual decision making, demarcating a noncondemning position on the practice.

Through the analyses performed in this study, the controversial and social mobilizing character that the practice of euthanasia aroused among the students was demonstrated, so that not only their belongings to the categories of students of medicine and law, but also to the categories of practitioners or not of religion, showed themselves to be polarizing forces for the different positions on euthanasia. Finally, these results lead us to consider that the delimitation and comprehension of the object in the construction of social representation is circumscribed by the anchorages of these groups, that is, by previous fields of knowledge that are fed by different social insertions and group memberships. Thus, the variations identified in this analysis can indicate both the construction of different realities and concepts about the practice of euthanasia, and a variation in the positioning of the group of belonging that impels the selection and reorganization of this practice in specific ways. One of the limits of this study was the limited number of participants in public higher education. Future studies could perform a comparison between the context of public and private undergraduate courses, revealing contextual dynamics linked to the ethical fields of formation of each profession and also allowing the exploration of the sociodemographic modulations of the enlarged sample.

\section{References}

Abric, J.-C. (1994). Pratiques et représentations sociales. Paris: Presses Universitaires de France.

Andrade, D. A. de. (2014). Representações sociais de velhice por diferentes grupos etários: Analisando estruturas e processos (Master's thesis, Programa de Pós-Graduação em Psicologia, Universidade Federal de Pernambuco, Recife, PE, Brazil).

Bastin, G., \& Bouchet-Valat, M. (2014). Media Corpora, Text Mining, and the Sociological Imagination - A free software text mining approach to the framing of Julian Assange by three news agencies using R.TeMiS. Bulletin of Sociological Methodology/Bulletin de Méthodologie Sociologique, 122(1), 5-25. https://doi.org/10.1177/0759106314521968 
Camargo, B. V., \& Justo, A. M. (2013). IRAMUTEQ: Um software gratuito para análise de dados textuais. Temas em Psicologia, 21(2), 513-518. https://doi.org/10.9788/TP2013.2-16

Carmona, D. S., Santos, F. de O., \& Fonseca, S. L. (2011). Bioética, Eutanásia e Psicologia: Tecendo algumas reflexões. Mnemosine, 7(2). Retrieved from http://mnemosine.com.br/ojs/ index.php/mnemosine/article/view/236

Diniz, D., \& Guilhem, D. (2017). O que é bioética. Brasília, DF: Brasiliense.

Felix, Z. C., Costa, S. F. G. da, Alves, A. M. P. de M., Andrade, C. G. de, Duarte, M. C. S., \& Brito, F. M. de. (2013). Eutanásia, distanásia e ortotanásia: Revisão integrativa da literatura. Ciência \& Saúde Coletiva, 18, 2733-2746. https://doi. org/10.1590/S1413-81232013000900029

Flament, C. (2001). Estrutura e dinâmica das representações sociais. In D. Jodelet (Ed.), As representações sociais (pp. 173-186). Rio de Janeiro, RJ: Editora da Universidade do Estado do Rio de Janeiro.

Godinho, A. M. (2017). Ortotanásia e cuidados paliativos: O correto exercício da prática médica no fim da vida. In A. M. Godinho, G. S. Leite, \& L. Dadalto (Eds.), Tratado brasileiro sobre o direito fundamental à morte digna (pp. 131150). São Paulo, SP: Almedina.

Kovács, M. J. (2003). Educação para a morte: Temas e reflexão. São Paulo, SP: Casa do Psicólogo.

Martin, L. (1998). Eutanásia e distanásia. In S. I. F. Costa, G. Oselka, \& V. Botle (Eds.), Iniciação a Bioética (pp. 171-192). Brasília, DF: Conselho Federal de Medicina.

Menezes, R. A., \& Ventura, M. (2013). Ortotanásia, sofrimento e dignidade: Entre valores morais, medicina e direito. Revista Brasileira de Ciências Sociais, 28(81), 213-229. https://doi. org/10.1590/S0102-69092013000100013
Morais, E. R. C. de. (2018). Conflitos bioéticos na demarcação dos limites da vida: Um estudo sobre as representações sociais de aborto $e$ eutanásia (Doctoral dissertation, Programa de Pós-Graduação em Psicologia, Universidade Federal de Pernambuco, Recife, PE, Brazil).

Moscovici, S. (1976). La psychanalyse, son image et son public. Paris: Presses Universitaires de France.

Oliveira, A., \& Amaral, V. R. (2007). A análise factorial de correspondências na investigação em psicologia: Uma aplicação ao estudo das representações sociais do suicídio adolescente. Análise Psicológica, 25(2), 271-293.

Ribeiro, D. C. (2006). Autonomia: Viver a própria vida e morrer a própria morte. Cadernos de Saúde Pública, 22, 1749-1754. https://doi. org/10.1590/S0102-311X2006000800024

Sá, C. P. de. (2002). Núcleo central das representações sociais. Rio de Janeiro, RJ: Editora da Universidade do Estado do Rio de Janeiro.

Santos, M. de F. de S. (2005). A teoria das representações sociais. In M. de F. de S. Santos \& L. M. de Almeida (Eds.), Diálogos com a teoria das representações sociais (pp. 13-38). Recife, PE: Editora Universitária da Universidade Federal de Pernambuco.

Santos, M. de F. de S., \& Almeida, L. M. de. (2005). Diálogos com a teoria da representação social. Recife, PE: Editora Universitária da Universidade Federal de Pernambuco.

Siqueira-Batista, R., \& Schramm, F. R. (2004). Eutanásia: Pelas veredas da morte e da autonomia. Ciência \& Saúde Coletiva, 9, 31-41. https://doi. org/10.1590/S1413-81232004000100004

Received: $02 / 07 / 2018$ $1^{a}$ revision: 03/12/2018 Accepted: 04/12/2018

(cc)BY (C) The Author(s), 2018. Open Access. This article is distributed under the terms of the Creative Commons Attribution 4.0 International License (http://creativecommons.org/licenses/by/4.0/), which permits unrestricted use, distribution, and reproduction in any medium, provided you give appropriate credit to the original author(s) and the source, provide a link to the Creative Commons license, and indicate if changes were made. 